\title{
ANALYSIS OF VALUE CHAIN CRISAN CUTTING INTEREST \\ (Case Study of Chrysanthemum Cut Flower Farmer Group in Sidomulyo Village, Batu District, Batu City)
}

\author{
Winda Dixi Yanuaristy ${ }^{1 *}$, Djoko Koestiono ${ }^{2}$, Abdul Wahib Muhaimin ${ }^{2}$ \\ ${ }^{1}$ Postgraduate, Faculty of Agriculture, Brawijaya University, Malang, Indonesia \\ ${ }^{2}$ Agricultural Socio-Economics Departement, Brawijaya University, Malang, Indonesia \\ *corresponding aoutor: windadx@gmail.com
}

\begin{abstract}
Abstrack : This study aims to analyze the value chain of chrysanthemum cut flower farmers. The object of this research is located in Sidomulyo Village, Kec. Batu, Stone Town. This research was conducted on 34 respondents of chrysanthemum cut flower farmers using the census method. Data analysis using the Value Chain Analysis method by Kaplinsky and Morris. The results of this study indicate that the chrysanthemum cut flower farmer groups in the village of Sidomulyo have a value chain, namely, collectors (Florist) $\rightarrow$ Event Organizer / Florist. Value Chain Mapping shows that all activities in the production of sudan chrysanthemum cut flowers are quite optimal, but there are 2 points that are lacking in outbound logistics and supporting activities in Product Segment Determination and Key Market Success Factors. Chrysanthemum cut flowers are influenced by price, constraints on delivery, packaging, flexibility and innovation
\end{abstract}

Keywords: Value Chain Analysis, Value Chain, Chrysanthemum Cut Flower

http://dx.doi.org/10.21776/ub.agrise.2021.021.2.6

Received 17 December 2020

Accepted 27 April 2021

Available online 30 April 2021

\section{INTRODUCTION}

The potential for floricultural commodities such as cut flowers in Indonesia itself is very diverse and abundant, such as data on cut flower production by plant type in the Indonesian Ornamental Plants Statistics data (2016) from 2013-2016 which states that the plant with the largest number of stem production per year is the chrysanthemum, which is equal to $433,100,145$ stalks and has increased from year to year. The Central Bureau of Ornamental Plants Statistics (2016) states that the Area of Harvest, Production, and Yield / $\mathrm{m} 2$ of Chrysanthemum Plants by Province in Java in 2016 the East Java region has the largest land area. namely $6,318,227 \mathrm{~m} 2$, with the least amount of production on the island of Java. And according to data on the Development of Planted Area, Harvested Area, Production and Productivity of Chrysanthemum in the four Production Center Areas in East Java (2008
- 2014) states that Batu City is the region that has the most volatile productivity data. This resulted in the authors choosing the Batu area as the location of the research location.

The fluctuating productivity is also caused by the competence of farmers in implementing good and correct technological innovations that have not been fully fulfilled. Whereas on the other hand, the market and consumers have wanted Chrysanthemum flowers with a quality standard that is more than what farmers have produced (Chakrabarti and Sarker, 2011 in Pratomo and Andri 2013). From the physical point of view of the chrysanthemum flowers in Sidomulyo Village, Batu District, Batu City itself, at every harvest there must be flower products which is deformed and damaged, like a small flower that grows imperfectly, which causes the farmer to lose. And the most influential thing is the fluctuation in the purchase of chrysanthemum cut flowers on holidays which are 
relatively busy and profitable and on quiet days which result in the production of chrysanthemum cut flowers being left in the garden to die and burned, this is very detrimental to flower farmers. cut the chrysanthemum.

Therefore, this study was conducted to determine the value chain of chrysanthemum cut flowers in the Bung Chrysanthemum Farmers Group in Sidomulyo Village, Batu District, Batu City, in order to obtain optimal results and be able to compete with Chrysanthemum cut flower centers in other areas.

\section{RESEARCH METHODOLOGY}

This type of research is descriptive using qualitative and quantitative approaches. The data analysis method used includes value chain analysis using VCA (Value Chain Analysis) which is divided into three stages, namely Identification of Actors as a Starting Point for Value Chain Analysis (The Point of Entry for Value Chain Analysis), Mapping the value chain, and Determination of Product Segments and Key Success Factors of the Destination Market (Product segments and Critical Success Factors in final markets).

The location of the research was conducted in Sidomulyo Village, Batu District, Batu City. The location selection was carried out purposively based on research and is a flower-producing center that can be used as a tourist attraction, especially for tourists visiting Batu City.

The sample to be taken in this research is farmers who cultivate chrysanthemum cut flowers, where the method of determining the respondents is all chrysanthemums cut flower farmers with 34 respondents and one of the farmer groups as the key informant. Meanwhile, respondents for marketing agencies used the snowball sampling method, namely by following the marketing flow of chrysanthemum cut flowers obtained through information from previous respondents, both farmers, wholesalers, and other retailers.

Collecting data in this study using several methods, namely interviews, observation, and literature study For data analysis used is, value chain analysis using VCA (Value Chain Analysis) which is divided into three stages, namely Identification of Actors as a Starting Point for Value Chain Analysis (The Point of Entry for Value Chain Analysis), Mapping value chains), and Determination of Product Segments and Key Success Factors of the
Destination Market (Product segments and Critical Success Factors in final markets).

\section{RESULT AND DISCUSSION}

Profile of Sidomulyo Village, Batu District, Batu City, Sidomulyo is a village in the subdistrict of Batu, Batu city, East Java Province, located about $3 \mathrm{~km}$ from the city center of Batu Village. Sidomulyo village is famous for flower agro-tourism or more popularly known as flower village. Lebuh of 1000 types of Bungan is cultivated in the village which has 3 hamlets namely, Tinjomoyo, Tonggolari, and Sukorembug. Geographically, Sidomulyo Village is located in the south at the foot of Mount Arjuno and is at an altitude of $800-85 \mathrm{~m}$ above sea level. With 17 '- $25^{\prime} \mathrm{C}$ with air temperature and fertile soil conditions. The majority of their livelihoods are as farmers. Where the village of Sidomulyo is known as the Flower Tourism Village because the majority of the people are farmers and traders of ornamental plants. Land Use and Village Potential, Most of the land in Sidomulyo Village is used as agricultural land. Area and use of agricultural land. Area and land use can be seen in the following table:

Tabel.1 Area and Land Use

\begin{tabular}{|c|l|r|r|}
\hline No. & $\begin{array}{l}\text { Type of Land } \\
\text { Use }\end{array}$ & $\begin{array}{c}\text { Area } \\
\text { (Hectare) }\end{array}$ & $\begin{array}{c}\text { Percentage } \\
(\mathbf{\%})\end{array}$ \\
\hline 1 & $\begin{array}{l}\text { Technical } \\
\text { Irrigation } \\
\text { Paddy }\end{array}$ & 184,021 & 67,95 \\
\hline 2 & Building & 1,5 & 0,55 \\
\hline 3 & Pool & 4,0 & 1,48 \\
\hline 4 & Settlement & 53,0 & 19,57 \\
\hline 5 & $\begin{array}{l}\text { Village's } \\
\text { Treasury Land }\end{array}$ & 14,506 & 5,36 \\
\hline 6 & Field & 1 & 0,37 \\
\hline 7 & Government & 2 & 0,74 \\
\hline 8 & Offices & & - \\
\hline 9 & Ooad (Km) & 42 & 1,11 \\
\hline \multicolumn{2}{|l|}{ Total } & $\mathbf{2 7 0 , 8 2 1}$ & $\mathbf{1 0 0}$ \\
\hline
\end{tabular}

Population Data of Sidomulyo Village by Livelihood, The total population in Sidomulyo Village, Batu Subdistrict, Batu City is 7,586 people, there is a balance between the female population of 3,885 people and the male population of 3,701 . Most of the villagers work as farmers and farm laborers and as many as 2,749 people are students and active students. 
Profile of Sidomulyo Village Chrysanthemum Cut flower Farmers, There are two types of chrysanthemum cut flower farmers in Sidomulyo Village, Batu District, Batu City, namely chrysanthemum cut flower farmers who join farmer groups and those who do not. The farmer who joins a farmer group based on cut chrysanthemum farming is called the Krisan Mulyo Joyo Farmer Group. Krisna Mulyo Joyo farmer group is a farmer group whose main commodity is chrysanthemum cut flowers in Batu City,

Table. 2 Data on the Number of Chrysanthemum Cut flower Farmers

\begin{tabular}{|c|c|c|c|}
\hline No & $\begin{array}{c}\text { Farmer } \\
\text { Membership }\end{array}$ & Percentage & Total \\
\hline 1 & $\begin{array}{l}\text { Krisan } \\
\text { Joyo }\end{array}$ & 76 & 26 \\
\hline 2 & Not Joined & 24 & 8 \\
\hline \multicolumn{2}{|r|}{ TOTAL } & 100 & 34 \\
\hline
\end{tabular}

The land area of chrysanthemum cut flower farmers in Sidomulyo Village, Batu District, Batu City is as follows:

Table. 3 Land area for Chrysanthemum Cut Flower Farmers

\begin{tabular}{|c|c|r|}
\hline No. & Area $(\mathrm{m} 2)$ & Farmers (people) \\
\hline 1 & $<250$ & 7 \\
\hline 2 & $251-500$ & 11 \\
\hline 3 & $501-750$ & 1 \\
\hline 4 & $751-1000$ & 5 \\
\hline 5 & $>1000$ & 10 \\
\hline 4 & $751-1000$ & 5 \\
\hline 5 & $>1000$ & 10 \\
\hline \multicolumn{2}{|c|}{ Total Land 31.720 } & 34 \\
\hline
\end{tabular}

From these data, it can be seen that the total land area of chrysanthemum cut flower farmers in Sidomulyo Village is $31,720 \mathrm{~m} 2$ or 3,172 ha with an average land area of $0.0932 \mathrm{ha}$.

Identification of Actors as a Starting Point for Value Chain Analysis (The Point of Entry for Value Chain Analysis), At this stage, identification is carried out first, namely, the main actors involved in the fulfillment of chrysanthemum cut flowers in Sidomulyo Village, Batu District, Batu City. The first value chain starts from the procurement of facilities and infrastructure for the production of chrysanthemum flowers cut, namely:

- Farmers (cultivation) $\rightarrow$ Suppliers for production infrastructure facilities $\rightarrow$ Chrysanthemum cut flower farmers

Chrysanthemum Cut flower Farmer Group Marketing Division:

- Collectors (Florist) $\rightarrow$ Event Organizer / Florist

The main activity in the chrysanthemum cut flower value chain in Sidomulyo Village includes the procurement of chrysanthemum cut flowers, namely farmers (producers). The marketing division of the chrysanthemum cut flower farmer group is as follows, namely, wholesalers (Florist) $\rightarrow$ Event Organizer / Florist. Where is the difference between wholesaler and EO / Florist is a trader who collects chrysanthemum cut flowers from farmers and sells to the final consumer, namely EO / florist, where the EO / florist is more specific in handling decoration and cut flower arrangements.

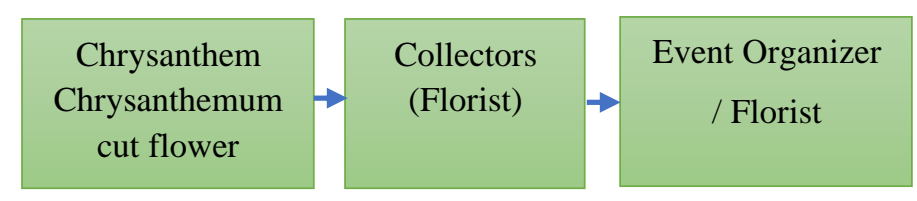

Mubiarto (1989) states that one of the marketing systems that is considered efficient is that if it is able to deliver/distribute products from farmers and producers to the final consumer at the lowest possible cost, it can be seen from this that the channels in the marketing chain are in the flower farmer groups. Chrysanthemum cut is included in an efficient marketing system because it distributes the produce from the farm from the farmer to the producer to the end consumer at a very low cost with few value chains in it.
Value Chain Mapping, The following is an explanation of the mapping of the chrysanthemum cut flower farmer group value chain,

A. Inward Logistics

a. Supply of cultivation facilities and $b$. Supplies of means

For the provision of cultivation facilities and equipment supplies, farmers with a partnership system obtain cultivation equipment, fertilizers, and pesticides from their private pockets by buying them at an agricultural shop, while for seeds they are 
provided by partners, namely traders, collectors (florists). As for labor, the activities of planting spraying, fertilizing, cutting, and irrigating farmers with an area of fewer than $750 \mathrm{~m}^{2}$ are still being done by the farmers themselves. All the flowers bloom at the same time so if the collectors at any time need sudden goods then there is still a supply of products in the chrysanthemum garden.

Determination of Product Segments and Key Success Factors of Destination Markets (Product segments and Critical Success Factors in final markets). The following is the result of the radar diagram from the answers of the end consumers of chrysanthemum cut flower consumers,

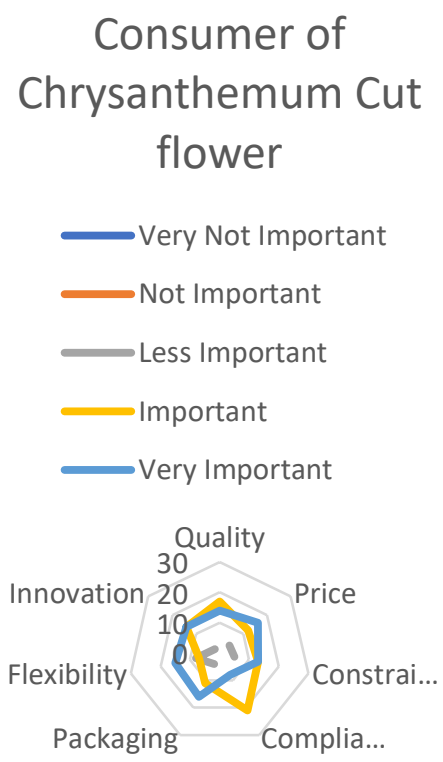

From the radar diagram, it can be concluded that the 7 important points in purchasing chrysanthemum cut flowers are influenced by price, shipping constraints, packaging, flexibility, and innovation.

Of the four points, it is a decision that greatly influences the purchase of cut flower chrysanthemums because most consumers come from EO / Florists who are selling more products from chrysanthemum cut flower farmers where these four things are very important to support the productivity of consumer companies. Several points above price, packaging, and innovation, such as promotional innovation, really influence the purchase of a product, as suggested by Rusyadi Abubakar (2005) and Dadun Abdul Manaf (2008) where the effect of packaging, price, and promotion simultaneously is positive and significant to the purchasing decision process. Meanwhile, the less influencing points fall into the important category of purchasing chrysanthemum cut flowers, namely quality and conformity to specifications.

Whereas for the quality of the chrysanthemum cut flowers in Sidomulyo Village itself, it is indeed less than in other chrysanthemum producing areas, but farmers have tried their best to improve the quality of their chrysanthemum cut flowers by the following counseling to replacement of superior seeds. As for conformity to consumer specifications, the chrysanthemum cut flowers have subscribed for a long time so that compliance with specifications is undoubtedly something that farmers and consumers already have an unwritten agreement on this matter.

\section{CONCLUSION}

1. So for Identification of Actors as a Starting Point for Value Chain Analysis (The Point of Entry for Value Chain Analysis)

On Chrysanthemum Cut Flower Farmers in Sidomulyo Village, Batu District, Batu City, Malang, there are two main actor value chains, namely the farmer value chain with a nonpartnership system where there is a flow as follows: collectors $\rightarrow$ wholesalers $\rightarrow$ final consumers, then marketing activity II, namely farmers with a partnership system, has the following flow: collectors (Florist) $\rightarrow$ Event Organizer / Florist.

2. On Value Chain Mapping (Mapping value chain)

It was found that all the activities involved in the production of Sudan chrysanthemum cut flowers were quite optimal, but there were 2 points that were lacking in outbound logistics and supporting activities, namely in for technology development and farmer research, it only focuses on development to support the production of chrysanthemum cut flowers flower production in 1 harvest period, So the total infrastructure cost of the production of chrysanthemum cut flowers for farmers with a partnership system related to assets and costs related to general and financial management is Rp. 8,359,422 / harvest season.

\section{b. Human Resource Management}

For recruitment itself, they usually use labor from the surrounding environment or invite 1-2 people to become employees, this recruitment is 
carried out only for farmers who have a land area of more than $750 \mathrm{~m}^{2}$ and only during the production process or planting flowers, namely at the time of hoeing, planting and harvesting.

For self-selection, farmers do what they are like as just work experience or even accept labor without selection and work while learning. For compensation and maintenance of employees, farmers with a partnership system do not do this because the work done by employees is only limited to assistance in several production activities, not employees who are involved in carrying out all production activities from the beginning of planting to harvest.

\section{c. Technology Development}

In the development of research and technology, farmer groups for the development of their own products usually receive counseling from the agricultural office, which is collected by the head of the chrysanthemum cut flower farmer groups, such as making fertilizer and treating plants. The rest is for the development of design improvements, the development of computer software based on the farmer's telecommunication system, they do not do this, they only learn from them, such as creating an account on Instagram or on Facebook.

\section{d. Purchase}

In the purchase, there is an inventory of raw materials or supplies. Where in the supply of raw materials or the supply of their own products for this type of agriculture, the chrysanthemum flower is harvested within 1 month because it is not marketing, and research and technology development. Where for marketing activities, farmers only rely on collectors as the estuary of purchases and only open promotions when the season turns to low buyers. Then for technology development and farmer research, it only focuses on development to support the production of chrysanthemum cut flowers extends to the development of communication technology.

3. In determining product segments and key success factors for the target market (Product segments and Critical Success Factors in final markets), it was found that consumers in the chrysanthemum cut flower farmer groups in purchasing chrysanthemum cut flowers were influenced by price, delivery constraints, conformity to specifications, packaging, flexibility, and innovation due to the end consumer is an event organizer or florist who wants a product that can be marketed again with a maximum condition in terms of specifications and minimal product damage during delivery.

\section{SUGGESTION}

1. It can be seen from the results of Identification of Actors as a Starting Point for Value Chain Analysis (The Point Of Entry For Value Chain Analysis) and Mapping of Value Chains for farmer groups in Sidomulyo village that have optimal value chains because they have few value chains in them. It's just that the mapping of the value chain is found in the marketing process and technology development and research is indeed very suboptimal and less in-depth, it only makes improvised development and lacks depth, such as creating websites or making apps that can be downloaded on Google Store which later it will greatly help reduce the risk in marketing which results in cut flowers not being sold optimally and being wasted in the garden.

2. From the results of determining the Product Segments and Key Success Factors of the Destination Market (Product segments and Critical Success Factors in final markets), the chrysanthemum cut flower farmer groups can see that consumers' desires, which later the farmers themselves can evaluate for the sustainability of their production and marketing system to be more sustainable. better in the future so that you can get more optimal results.

3. It is hoped that the next researchers can perform value chain analysis on chrysanthemum cut flower farmers in the village of Sidomulyo, Batu District, Batu City with 8 complete methods in Value Chain Analysis by Kaplinsky and Morris.

\section{ACKNOWLADGEMENT}

Thank you for all the parties involved in the work on this thesis which I cannot mention one by one, without you I would be nothing.

\section{REFERENCES}

Arimbawa Dika Putu. 2017. Pengaruh Luas Lahan, Teknologi Dan Pelatihan Terhadap Pendapatan Petani Padi Dengan Produktivitas Sebagai Variabel Intervening Di Kecamatan Mengwi. Jurnal EP. Jurusan Ekonomi Pembangunan Fakultas Ekonomi dan Bisnis Universitas Udayana. 
Dadun Abdul Manaf.2005. "Pengaruh Kemasan Terhadap Proses Keputusan Pembelian Minuman Penambah Stamina".

Bateman S. Thomas \& Snell A. Scott. 2008. Manajemen Kepemimpinan dan Kolaborasi dalam Dunia yang Kompetitif. Jakarta : Salemba Empat.

Brighton Mvumi Learnmore Tatenda Matsikira Jackqeline Mutambara , (2016),"The banana postharvest value chain analysis in Zimbabwe", British Food Journal, Vol. 118 Iss 2 pp. $272-28$

Direktorat Jendral Hortikultura, Kementrian Pertanian. 2018. http://hortikultura.pertanian.go.id/?p=2332 . Diakses pada 18 Juli 2018

Heizer Jay \& Render Barry. 2008. Operations Management Edisi Ketujuh. Jakarta: Salemba Empat

Kaplinsky Raphael dan Morris Make. 2000. Buku Pegangan Value Chain. Workshop Bellagio

Kusno, T.S., K.B. Andri. 2011. Laporan Rancang Bangun Pengembangan Agribisnis Tanaman Bunga Krisan di Propinsi Jawa Timur, Dinas Pertanian Propinsi Jawa Timur. Surabaya.

Mubiarto (1989) dalam Jurnal Sains Terpadu D. Iswan Riswandi dan Wawan Oktariza (2015). “Analisis Margin dan Efisiensi Pemasaran Ikan Bandeng dan Ikan Tongkol di DKI Jakarta

Pierce II A. John \& Robinson, Jr. B. Richard. 2007.Manajemen Strategi. Jakarta : Salemba Empat.

Pratomo A. G., Andri K. B. 2013. Analisis Rantai Pasok Dan Rantai Nilai Bunga Krisan Di Daerah Sentra Pengembangan Jawa Timur, Balai Pengkajian Teknologi Pertanian (BPTP) Jawa Timur.

Purwanto W. Arie \& Martini Tri. 2009. Krisan Bunga Seribu Warna. Yogyakarta : KANISIUS.

Purwono Joko, Sugyaningsih Sri, dan Fajriah Nada. 2014. Analisis Tataniaga Bunga Krisan Di Kecamatan Cugenang, Kabupaten Cianjur. Jurnal NeO-Bis, Volume 8, No. 2.
Rusyadi Akbar.2005. Pengaruh PelaksanaanBauran Pemasaran Terhadap Proses Keputusan Pembelian Konsumen pada Jamu di banda Aceh

Satriawan I Ketut. 2002. Rantai Nilai Bunga Potong Heliconia Caribaea Desa Kerta, Kecamatan Payangan, Kabupaten Gianyar, Provinsi Bali. Jurnal Skripsi Jurusan Teknologi Industri Pertanian. Fakultas Teknologi Pertanian. Universitas Udayana.

Nuryanto Hery. 2007. Budidaya Tanaman Krisan. Ganeca Exact

Pierce II A. John \& Robinson, Jr. B. Richard. 2007.Manajemen Strategi. Jakarta: Salemba Empat.

Pratomo A. G., Andri K. B. 2013. Analisis Rantai Pasok Dan Rantai Nilai Bunga Krisan Di Daerah Sentra Pengembangan Jawa Timur, Balai Pengkajian Teknologi Pertanian (BPTP) Jawa Timur.

Purwanto W. Arie \& Martini Tri. 2009. Krisan Bunga Seribu Warna. Yogyakarta: KANISIUS.

Purwono Joko, Sugyaningsih Sri, dan Fajriah Nada. 2014. Analisis Tataniaga Bunga Krisan Di Kecamatan Cugenang, Kabupaten Cianjur. Jurnal NeO-Bis, Volume 8, No. 2.

Rusyadi Akbar.2005. Pengaruh PelaksanaanBauran Pemasaran Terhadap Proses Keputusan Pembelian Konsumen pada Jamu di banda Aceh

Satriawan I Ketut. 2002. Rantai Nilai Bunga Potong Heliconia Caribaea Desa Kerta, Kecamatan Payangan, Kabupaten Gianyar, Provinsi Bali. Jurnal Skripsi Jurusan Teknologi Industri Pertanian. Fakultas Teknologi Pertanian. Universitas Udayana.

Setiyawan Deni. 2015. Analisis Pemasaran Krisan (Chrysanthemum Indicum L) Studi Kasus Di Kelompok Tani Srirejeki Desa Jetis Kecamatan Bandungan Kabupaten Semarang. Jurnal AGROMEDIA,Vol 34, No. 1.

Setiawati Nur. 2014. Analisis Rantai Nilai Cabai di Sentra Produksi Kabupaten Majalengka Jawa Barat. Jurnal Tesis Institut Pertanian Bogor.

Sistem Informasi Manajemen Pembangunan di Pedesaan, BAPPENAS. 2000. Kantor Deputi Menegristek Pendayagunaan dan Pemasyarakatan Ilmu Pengetahuan dan Teknologi.

Statistik Tanaman Hias Indonesia. 2016. Badan Pusat Statistik Indonesia 
Suyanto M. 2007. Strategic Management Global Most Admired Companies. Yogyakarta: ANDI OFFSET
Syibil Muhammad. 2013. Analisis Rantai Nilai Pada Komoditas Jamur Tiram Putih Di Kabupaten Bogor (Studi Kasus Pada P4s Nusa Indah). Jurnal Skripsi. Alih Jenis Manajemen. Departemen Manajemen. Fakultas Ekonomi Dan Manajemen. Institut Pertanian Bogor. 
This page is intentionally left blank 